\title{
PEMAKAIAN FLY-ASH SEBAGAI CEMENTITIOUS PADABETON MUTU TINGGI DENGAN STEAM CURING (THE USE OF FLY-ASH AS CEMENTITIOUS ON HIGH-STRENGTH CONCRETE WITH STEAM CURING)
}

\author{
Erwin Rommel ${ }^{1} \&$ Yunan Rusdianto $^{2}$ \\ Jurusan Teknik Sipil Fakultas Teknik Universitas Muhammadiyah Malang \\ Alamat Korespondensi :Jalan Raya Tlogomas 246 Malang 65144 \\ email : erwin67pro@yahoo.com HP 08123314432
}

\begin{abstract}
The use of fly-ash as cementitious will be made to utilize physical and chemical properties of fly-ash that has a dominan of silica and good of modulus fines. The use of steam curing will be done in this study which can speed up the cycle of making concrete. This is advantageous in the production of precast concrete and velocity field construction.

The research was conducted by making concrete cube $15 \times 15 \times 15 \mathrm{~cm}$ for 80 pieces and then tested the compressive strength and absorption of concrete. Achieve the quality of concrete made with the provision of K600 with giving the fly-ash respectively 7.5\%, 15\% and 30\% by weight of cement.

The results of the research obtained by the use of fly-ash as much as $7.5 \%$ as a cementitious that was given to the steam curing will provide the initial strength of concrete reached $47 \%$ of compressive strength at 28 days. While the effect of giving fly-ash in concrete has not seen absorption significantly when compared to concrete without fly-ash.
\end{abstract}

Key word : concrete, fly-ash, steam curing

\section{PENDAHULUAN}

Dengan makin meningkatkan keinginan konsumen untuk mendapatkan konstruksi berbahan beton serta memenuhi persyaratan lingkungan, maka dibutuhkan beton yang tidak saja mampu dari aspek kekuatan tetapi aspek ketahanan "durabilitas" terhadap lingkungan agresif semakin diminati. Berbagai terobosan pembuatan beton yang dapat memenuhi kedua aspek tersebut harus juga diimbangi dengan penyediaan material beton yang cepat dilapangan, seperti konstruksi pracetak.

Pembuatan beton dengan sistem bertekanan merupakan salah satu penyelesaian permasalahan diatas guna mempercepat waktu pembuatan dan produksi beton dilapangan. Tetapi kondisi tersebut membuat lapisan beton menjadi lebih porous karena pemberian tekanan pada suhu panas menyebabkan rusaknya lapisan terluar dari beton, karena semen sebagai material yang paling halus akan mudah mengalami susut-regang yang besar jika tekanan yang diberikan terlalu lama pada suhu yang tinggi.

HES (High-Early-Strength) Concrete menggunakan campuran beton yg mengandalkan penggunaan kadar semen yang tinggi dan akselerator untuk meningkatkan kecepatan perkembangan kekuatannya. Hasil penelitian tersebut menjelaskan bahwa metode konvensional untuk meningkatkan kekuatan awal beton dengan menggunakan kadar semen tinggi dan akselerator dapat meningkatkan susut suhu dan susut kering pada beton. Penyusutan yang tertahan pada kondisi aktual di lapangan menimbulkan tegangan tarik sehingga terjadi retak mikro yang akan meningkatkan permeabilitas beton serta mempercepat berbagai proses deteriorasi (kerusakan). Sehingga dapat digunakan serat untuk mengontrol retak mikro akibat susut pada beton tersebut. Hasil uji laboratorium dan uji lapangan menunjukkan ketahanan jangka pendek yang cukup tinggi pada beton HES yang menggunakan serat 
selulosa terhadap retak akibat susut beton. (Soroushian and Ravanbakhsh, 1999)

Penelitian ini akan memberikan alternatif pemakaian fly-ash sebagai bahan pengganti semen yang memiliki sifat alkalis sebagai perekat "sama dengan semen”, juga memiliki butiran material halus yang dapat berfungsi sebagai filler pada beton. Perubahan karakteristik pada beton yang diberi flyash akan dilihat sejauh mana pengaruhnya akibat pemberian tekanan pada saat perawatan dengan metode steam curing. Hal ini dapat membuat material beton yang unggul tidak saja dari sisi kekuatan tetapi memiliki keunggulan dalam kecepatan produksinya dibandingkan dengan beton konvensional "masa perawatan selama 28 hari”.

Pengaruh fly ash sebagai bahan tambah mengakibatkan terjadi reaksi pengikatan kapur bebas yang dihasilkan dalam proses hidrasi semen oleh silika yang terkandung dalam fly ash. Selain itu, butiran fly ash yang jauh lebih kecil membuat beton lebih padat karena rongga antara butiran agregat diisi oleh fly ash sehingga dapat memperkecil pori-pori yang ada dan memanfaatkan sifat pozzolan dari fly ash untuk memperbaiki mutu beton. Fly ash merupakan bahan tambah yang bersifat aktif bila dicampur dengan kapur atau semen, dan beton dengan campuran fly ash memiliki kuat tekan lebih tinggi daripada beton normal pada komposisi tertentu. Penggunaan fly ash memperlihatkan dua pengaruh abu terbang di dalam beton yaitu sebagai agregat halus dan sebagai pozzolan. Selain itu abu terbang di dalam beton menyumbang kekuatan yang lebih baik dibanding dengan beton normal (Shann, 1994). Persyaratan komposisi kimia fly-ash menurut SNI dijelaskan pada Tabel-1.

Tabel 1. Persyaratan Kimia Abu Terbang

\begin{tabular}{lc}
\hline \multicolumn{1}{c}{ Unsur kimia } & Kadar (\%) \\
\hline Jumlah Oksida & 70 \\
$\mathrm{SiO}_{2}+\mathrm{Al}_{2} \mathrm{O}_{3}+\mathrm{Fe}_{2} \mathrm{O}_{3}$ minimum & \\
$\mathrm{SO}_{3}$ maksimum & 5 \\
Hilang pijar maksimum & 6 \\
Kadar air maksimum & 3 \\
Total alkali dihitung sebagai & 1,5 \\
$\mathrm{Na}_{2}$ Omaksimum & \\
\hline
\end{tabular}

Penggunaan pozzolan alami pada mortar tanpa semen (campuran kapur ;pozzolan;pasir) pasca umur 3 tahun mengalami perubahan sifat mekanik tergantung pada campuran bahan dan perawatan mortar tersebut. Penurunan mekanik tersebut terjadi secara bertahap tergantung pada kelembaman dan kondisi awal mortar. Sifat-sifat mekanik mortar yang diberi material pozzolan menjadi lebih tahan pada lingkungan dengan tingkat salinitas yang tinggi dibandingkan dengan mortar konvensional (Velosa and Veiga, 2005)

Beton yang dibuat dari semen yang mengandung material pozzolan atau disebut semen PPC memiliki permeabilitas lebih rendah dibandingan dengan beton normal yang memakai semen tipe-1. Tetapi perbedaan sifat permeabilitas tersebut hanya terjadi sampai umur hidrasi 20 hari, bahkan pada umur beton 90 hari permeabilitas berkurang hingga 50\% dibanding dengan beton memakai semen tipe-1 (Alit Karyawan, 2007)

Penelitian pemakaian abu ketel sebagai pengganti semen juga telah dilakukan untuk memperbaiki kuat tekan mortar dan beton mutu tinggi beton dengan perawatan memakai steam curing pada suhu $30^{\circ} \mathrm{C}$ samapai $50^{\circ} \mathrm{C}$ selama 10 jam, 2 hari dan 3 hari. Dengan memakai abu ketel 5\% dari berat semen, kuat tekan beton mutu tinggi meningkat seiring dengan kenaikan suhu steam curing yang diberikan, kenaikannya mencapai 49,81\% dibandingkan dengan perawatan beton memakai metode konvensional (moist curing method) (Irianti, 2007)

Penggunaan material trass sebagai pozzolan untuk mengganti sebagian semen pada pembuatan beton mutu tinggi juga telah dilakukan, dimana kelemahan dari campuran tersebut adalah lamanya waktu pengikatan semen sehingga dilakukan alternatif perawatan dengan metode penguapan atau steam curing. Dengan pemberian penguapan pada beton tersebut selam 6 jam pada suhu $60^{\circ} \mathrm{C}$ menghasilkan kuat tekan yang sama dengan beton yang diberi perawatan dengan cara perendaman selama 28 hari, demikian juga untuk nilai modulus elastisitas beton dimana nilainya lebih besar 8,34\% pada beton dengan material pozzolan trass yang diberi penguapan dibandingkan beton konvensional (Hidayat, 2008).

Tujuan dari penelitian ini yang ingin dicapai adalah mendapatkan kekuatan dan durabilitas beton mutu tinggi yang optimal dengan memakai bahan flay 
ash sebagai cementious pada beton dengan perawatan steam.

\section{METODE PENELITIAN}

\section{Rancangan Penelitian}

Penelitian ini merupakan kelanjutan penelitian sebelumnya (Erwin, 2010) yang menguji beton memakai bahan pozzolan (semen pozzolan) yang diberi perawatan steam. Pada penelitian sekarang dilakukan penggantian bahan pozzolan memakai bahan limbah flay-ash yang digunakan sebagai pengganti atau cementitious sebagian semen untuk pembuatan material beton mutu tinggi (rencana mutu beton K600), serta diberi perlakuan steam curing selama 6,5 jam pada suhu $70-80^{\circ} \mathrm{C}$. Jumlah bahan flay ash yang digunakan sebagai pengganti sebagian semen diberikan pada komposisi berat, masing-masing perlakuan 0\% (tanpa flay ash), 7,5\%, 15\%, 30\% dari berat total semen yang digunakan. Sedangkan variable terikat yang akan dihasilkan adalah kekuatan beton, serapan air pada beton. Penelitian dilakukan di laboratorium Pabrik Beton Pracetak WIKA BETON Jawa Timur untuk pembuatan dan perawatan benda uji serta pengujian beton. Jumlah dan rancangan benda uji yang digunakan dapat dilihat pada Tabel-2.

Tabel 2. Rancangan benda uji

\begin{tabular}{cccccc}
\hline Iutu Beton & $\begin{array}{c}\text { Komposisi } \\
\text { pemakaian flay } \\
\text { ash } \\
(\mathbf{\% )}\end{array}$ & $\begin{array}{c}\text { Metode } \\
\text { Perawatan }\end{array}$ & $\begin{array}{c}\text { Durasi } \\
\text { Pemberian } \\
\text { tekanan } \\
\text { (jam) }\end{array}$ & $\begin{array}{c}\text { Jenis } \\
\text { Pengujian }\end{array}$ & $\begin{array}{c}\text { Jumlah } \\
\text { BU tiap } \\
\text { pengujian }\end{array}$ \\
\hline 0 & & & Uji Kuat Tekan & 15 \\
& 0 & & Uji Penyerapan & 5 \\
$\mathbf{K 6 0 0}$ & 7,5 & Uji Kuat Tekan & 15 \\
& 7,5 & Steam & Uji Penyerapan & 5 \\
& 15 & Curing & & Uji Kuat Tekan & 15 \\
& 15 & & Uji Penyerapan & 5 \\
& 30 & & Uji Kuat Tekan & 15 \\
& 30 & & Uji Penyerapan & 5 \\
\hline
\end{tabular}

*) pengujian tekan dilakukan pada umur ; 7 ; 14; dan 28 hari, @ 5 benda uji

Perancangan Campuran dan Kebutuhan Bahan Beton

Perancangan campuran beton memakai metode SNI 03-2834-2000. Bahan agregat yang dipakai pada kondisi SSD (saturated surface dry), akan tetapi untuk penyesuaian kondisi kadar air agregat dilapangan dengan dilaboratorium, dibuat koreksi perhitungan volume campuran dengan bahan yang dipakai. Perancangan campuran beton yang telah dibuat untuk mutu beton K-600 (beton mutu tinggi) akan diperoleh kebutuhan bahan penyusun per-meter kubik beton dan dilakukan koreksi pada kondisi kadar air agregat dilapangan. Beberapa variasi komposisi campuran beton dengan memakai fly-ash sebagai cementitious seperti terlihat pada Tabel-3.

Tabel-3 : Kebutuhan bahan penyusun per-meter kubik beton

\begin{tabular}{|c|c|c|c|c|c|c|c|c|}
\hline \multirow{3}{*}{ Material } & \multicolumn{4}{|c|}{ Volume beton awal } & \multicolumn{4}{|c|}{ Volume beton setelah dikoreksi } \\
\hline & \multirow{2}{*}{ Tanpa fly-ash } & \multicolumn{3}{|c|}{ Kandungan fly-ash } & \multirow{2}{*}{$\begin{array}{l}\text { Tanpa } \\
\text { fly-ash }\end{array}$} & \multicolumn{3}{|c|}{ Kandungan fly-ash } \\
\hline & & $7.5 \%$ & $15 \%$ & $30 \%$ & & $7.5 \%$ & $15 \%$ & $30 \%$ \\
\hline men (kg) & 603 & 558 & 512 & 422 & 603 & 558 & 512 & 422 \\
\hline$y$-ash (kg) & - & 45 & 91 & 181 & - & 45 & 91 & 181 \\
\hline lit (kg) & 1012 & 1012 & 1012 & 1012 & 1039 & 1039 & 1039 & 1039 \\
\hline $\operatorname{sir}(\mathrm{kg})$ & 620 & 620 & 620 & 620 & 633 & 633 & 633 & 633 \\
\hline$r(\mathrm{~kg})$ & 205 & 205 & 205 & 205 & 165 & 165 & 165 & 165 \\
\hline
\end{tabular}




\begin{tabular}{lcccccccc}
\hline $\begin{array}{l}\text { srat Isi } \\
\text { g/m }{ }^{3} \text { ) } \\
\text { ktor air }\end{array}$ & 2440 & 2567 & 2522 & 2440 & 2440 & 2567 & 2522 & 2440 \\
men, w/c & 0,34 & 0,37 & 0,40 & 0,485 & 0,27 & 0,29 & 0,32 & 0,39 \\
\hline
\end{tabular}

\section{Perawatan Beton}

Perawatan benda uji dilakukan dengan cara dialirkan uap panas bertekanan kedalam beton (steam curing). Beton yang telah diaduk dimasukkan kedalam cetakan kubus (15x15x15) cm, kemudian bersamasama cetakan beton dimasukkan kedalam box steam bertekanan dan dialirkan uap panas dengan waktu awal 30 menit (sampai tekanan stabil mencapai suhu 70 sampai $80{ }^{\circ} \mathrm{C}$ didalam box steam) kemudian dibiarkan selama 3 jam dan setelah itu katup tekanan dimatikan selama 30 menit untuk proses pendinginan. Sehingga total variasi lama pemberian steam adalah 6,5 jam. Skema lengkap pemberian suhu dan tekanan uap dapat dilihat pada Gambar-1.

Alat yang digunakan dalam penelitian ini adalah alat Steam Curing dengan skala Laboratorium yaitu kotak beton persegi berukuran $(200 \times 100 \times 100) \mathrm{cm}$. Sedangkan uap yang digunakan dalam perawatan benda uji berasal dari boiler yang disalurkan melalui pipa uap

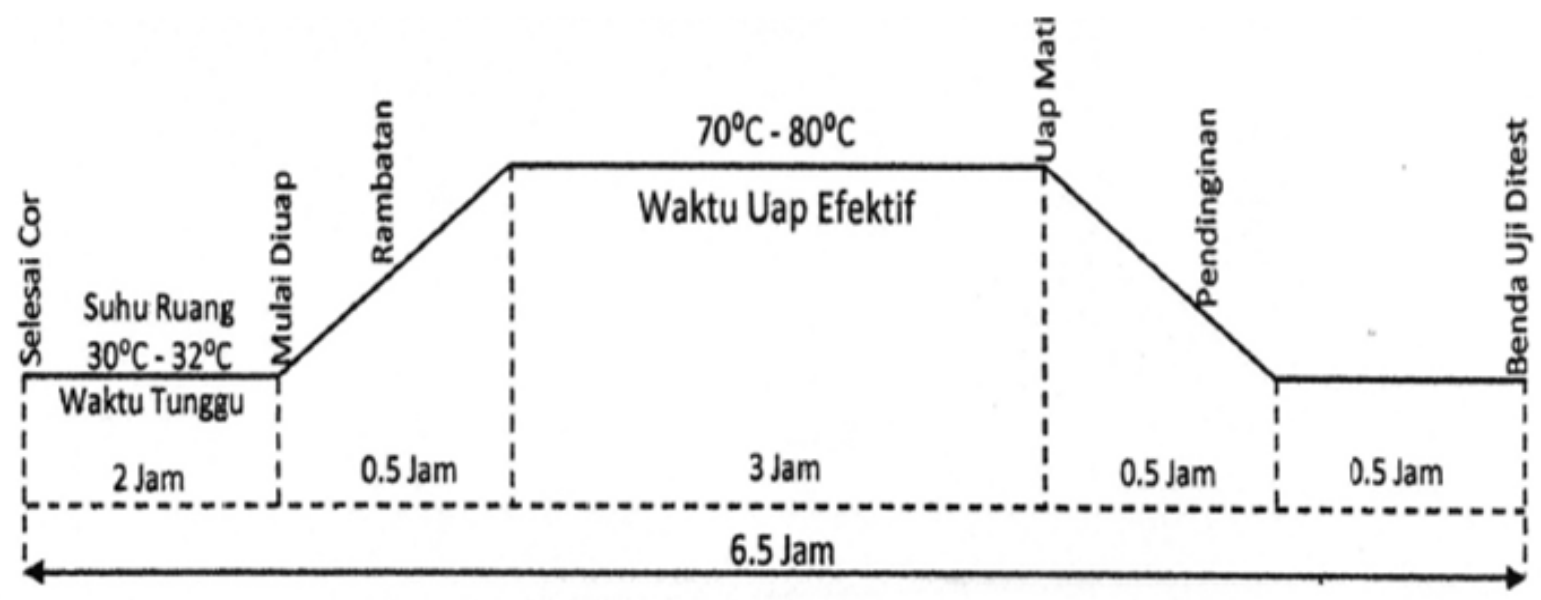

Gambar-1 : Pemberian suhu dan waktu tekanan pada alat steamer

\section{Proses Pengujian}

Pengujian dilakukan setelah beton di steam dan dibiarkan pada suhu ruangan sampai umur pengujian yang diinginkan, yaitu umur : 7, 14 dan 28 hari . Pengujian kekuatan dilakukan dengan mesin tekan (compression machine testing), dimana benda uji diletakkan secara simetris kemudian diberi beban yang konstan. Pembebanan dilakukan sampai benda uji hancur dan dicatat beban maksimum yang terjadi. Sedangkan untuk pengujian serapan air dilakukan pada umur beton sudah mencapai 28 hari. Pengujian serapan air pada beton bersifat non-destructive. Alur penelitian selengkapnya dapat dilihat pada Gambar-2.

\section{Peralatan Penelitian}

Penelitian utama yang digunakan pada penelitian ini antara lain ; Mesin Uji Tekan kapasitas 2000 kN, Steamer Tank (alat steam curing) ukuran (200x200x100) cm; water tank; oven dengan kapasitas $\operatorname{suhu}(110 \pm 5)^{0} \mathrm{C}$;

\section{Bahan Campuran Beton}

Semen, digunakan Semen Portland (PC); Agregat Halus (pasir) ; Agregat Kasar dipakai batu pecah split 1/2; bahan flay ash dari sisa pembakaran batu bara PLTU Paiton Jawa Timur 


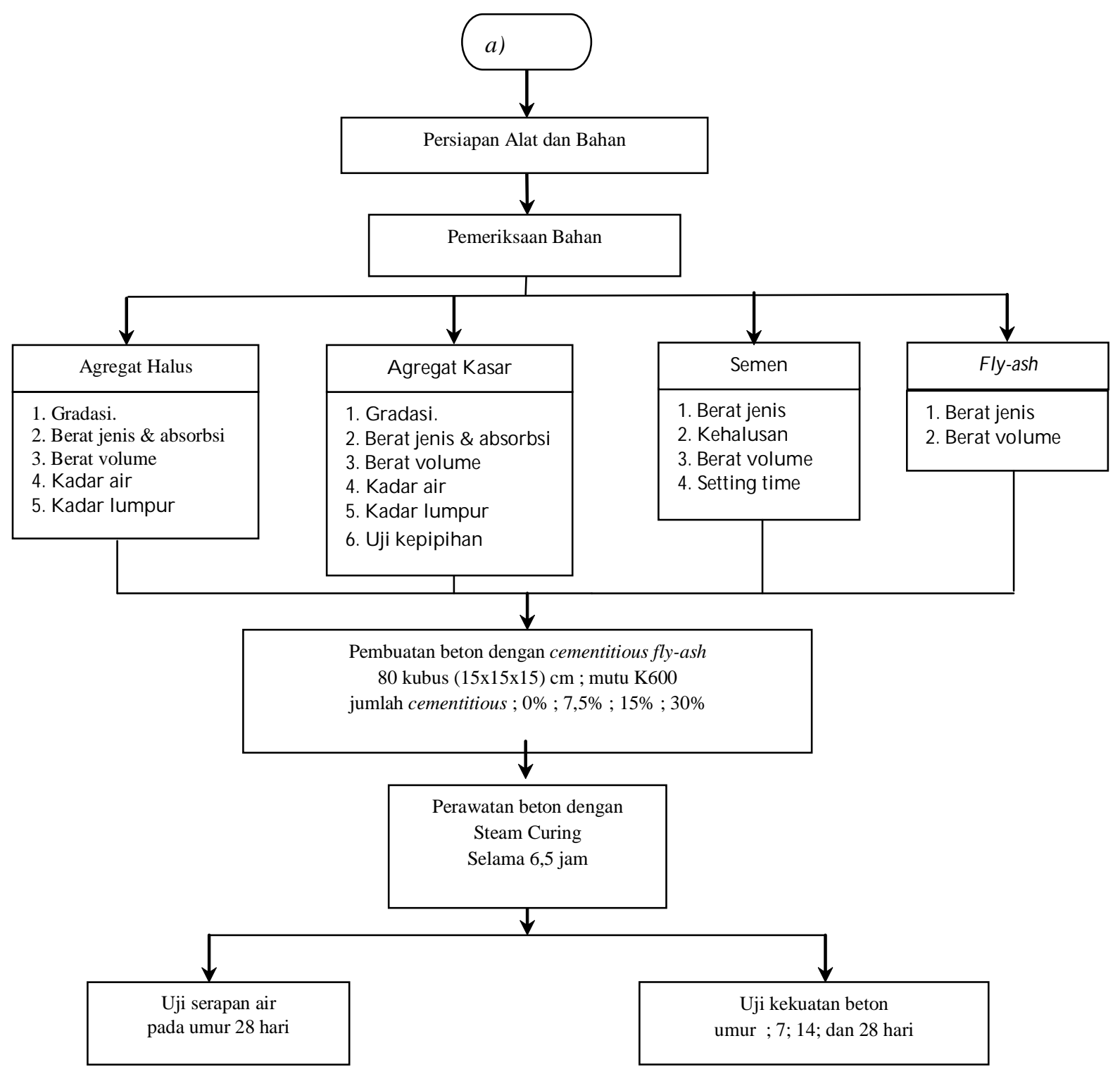

Gambar-2 : Alur penelitian

\section{HASILDAN PEMBAHASAN}

\section{Pemeriksaan Semen dan Fly-ash}

Pemeriksaan dilakukan pada berat jenis, berat volume dan kehalusan masing-masing material semen dan fly-ash. Berdasarkan hasil pemeriksaan yang tercantum pada grafik setting time, diperoleh waktu ikat awal (initial setting time) semen selama 110 menit dan fly-ash selama 255 menit yang di plotting saat penetrasi pada alat vicat sebesar $25 \mathrm{~mm}$, sedangkan waktu ikat akhir (final setting time) diperoleh masing-masing 160 menit dan 320 menit untuk semen dan fly-ash yang diukur ketika pembacaan penetrasi vicat menunjukkan angka nol
Tabel-4 : Hasil Pemeriksaan Semen dan Flyash

\begin{tabular}{lccc}
\hline \multicolumn{1}{c}{$\begin{array}{c}\text { Parameter } \\
\text { pengujian }\end{array}$} & satuan & Semen & $\begin{array}{c}\text { Fly- } \\
\text { ash }\end{array}$ \\
\hline Berat jenis & $\left(\mathrm{gr} / \mathrm{cm}^{3}\right)$ & 3.15 & 2,53 \\
Berat volume & $\left(\right.$ ton $\left./ \mathrm{m}^{3}\right)$ & 1.26 & 1,22 \\
$\begin{array}{l}\text { Kehalusan } \\
\text { Initial Setting }\end{array}$ & $(\%)$ & 6,00 & 10,1 \\
time & (menit) & 110 & 255 \\
$\begin{array}{l}\text { Final setting } \\
\text { time }\end{array}$ & (menit) & 160 & 320 \\
\hline
\end{tabular}




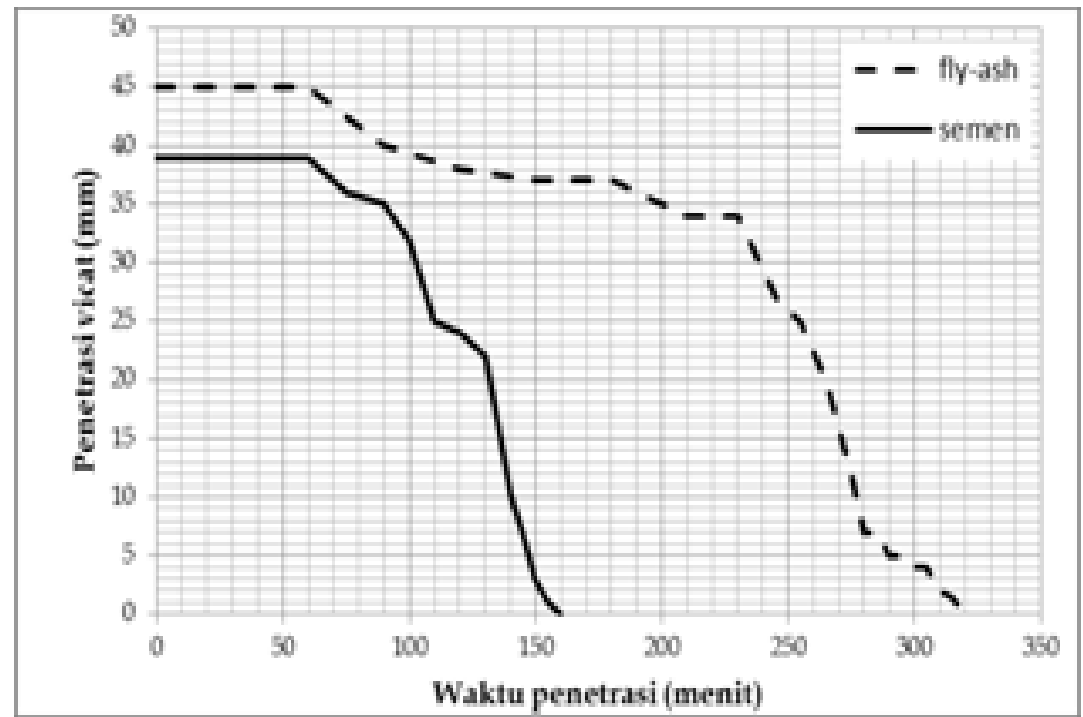

Gambar-3 : Grafik Setting Time Semen dan fly-ash

Dari hasil pengujian nilai slump menunjukkan bahwa nilai slump menurun seiring bertambahnya persentase fly ash dalam campuran beton. Hal ini menunjukkan bahwa fly ash dapat menyerap air dengan baik. Beton mutu tinggi menggunakan nilai fas rendah, berarti air yang digunakan sangat sedikit, sehingga nilai slump rendah. Jadi dapat disimpulkan bahwa penambahan fly ash berpengaruh terhadap nilai slump, makin besar persentase fly ash pada adukan beton maka nilai slump makin kecil.

Tabel-5 : Hasil Uji Slump Beton

\begin{tabular}{cc}
\hline $\begin{array}{c}\text { Kandungan Fly- } \\
\text { ash } \\
\text { pada beton }\end{array}$ & $\begin{array}{c}\text { Nilai Slump } \\
\text { (cm) }\end{array}$ \\
\hline Tanpa fly-ash & 10 \\
$7.5 \%$ & 9,5 \\
$15 \%$ & 11 \\
$30 \%$ & 12 \\
\hline
\end{tabular}

\section{Kuat Tekan Beton}

Pada Gambar-4 menjelaskan bahwa pemberian fly-ash sebagai cementitious pada campuran beton cukup berpengaruh pada kekuatan beton. Pemberian perawatan dengan cara dialiri uap panas (steam curing) juga memberikan peningkatan kekuatan awal beton cukup signifikan. Campuran beton konvensional (tanpa pemberian fly-ash) yang diberi perawatan steam curing dapat menghasilkan kekuatan beton mencapai $360 \mathrm{~kg} / \mathrm{cm}^{2}$ atau mencapai 53\% dari kekuatan beton pada umur 28 hari, sedangkan pada beton yang diberi fly-ash sebesar 7,5\% kuat tekannya sudah mencapai $47 \%$ yakni sebesar $331 \mathrm{~kg} / \mathrm{cm}^{2}$. Kenaikan tersebut tidak berlaku bagi campuran beton yang diberi fly-ash, sebagai pengganti sebagian semen, dimana justru dengan makin banyak pemberian flyash sebagai cementitious peningkatan awal kekuatan beton pasca steam tidak terjadi bahkan mengalami penurunan kekuatan awal. Kekuatan beton yang tanpa diberi steam curing (perawatan beton dengan cara perendaman atau konvensional) memiliki nilai yang lebih besar dibandingkan dengan beton yang diberi steam. Kenaikan kuat tekan beton tersebut mencapai $713 \mathrm{~kg} / \mathrm{cm}^{2}$ atau meningkat 5\% dibandingkan dengan beton yang diberi perawatan dengan steam curing dan tanpa diberi fly-ash.

Beton dengan diberi steam curing memiliki kekuatan awal yang lebih baik dibandingkan beton dengan perawatan konvensional, dimana kuat tekan awal beton dapat mencapai diatas setengah dari kuat tekan yang direncanakan setelah steam diberikan. Hal ini menjelaskan bahwa yang menjadi kelebihan dari pemberian steam curing tersebut bukan kuat tekan setelah umur 28 hari tetapi proses akselerasi hidrasi semen yang dapat dimanfaatkan untuk mempercepat proses pelaksanaan pekerjaan beton. Sedangkan pada umur beton 28 hari kekuatan beton tertinggi diperoleh pada pemakaian fly-ash sebanyak 7,5\% dimana kuat tekan yang dicapai sebesar $702 \mathrm{~kg} / \mathrm{cm}^{2}$ atau lebih besar $3 \%$ dibandingkan dengan beton konvensional (tanpa fly-ash). Tetapi pada umur beton 28 hari, pemakaian 
fly-ash sampai $15 \%$ sebagai cementitious dapat mencapai kekuatan beton yang direncanakan sebesar $600 \mathrm{~kg} / \mathrm{cm}^{2}$ (atau K600). Kecendrungan perilaku perjalanan kuat tekan beton tersebut juga sama pada berbagai umur beton yakni pada 7 dan 14 hari.

Perilaku penurunan kekuatan beton ini didukung oleh workability saat pembuatan beton dimana pemakaian fly-ash mempengaruhi jumlah air atau faktor air semen pada campuran beton. Faktor air semen meningkat dengan pemakaian fly-ash, dimana fas masing-masing 0,$27 ; 0,29 ; 0,32$ dan 0,39 untuk beton konvensional (tanpa fly-ash) ; 7,5\% FA; 15\%
FA; dan 30\% FA. Peningkatan pemakaian jumlah air pada campuran mempengaruhi kekuatan awal beton. Fly-ash sebagai bahan pengganti semen belum dapat bereaksi secara sempurna dengan air pada proses hidrasi semen. Hal tersebut didukung dari uji nilai slump untuk masing-masing campuran dimana pada pemakaian 30\% fly-ash menghasilkan nilai slump 12 $\mathrm{cm}$, dimana nilai sudah berada diluar batas nilai slump yang direncanakan yakni 8 sampai $12 \mathrm{~cm}$. Hubungan antara nilai slump dan pemakaian jumlah fly-ash sebagai cementitious dapat dilihat pada Gambar-5.

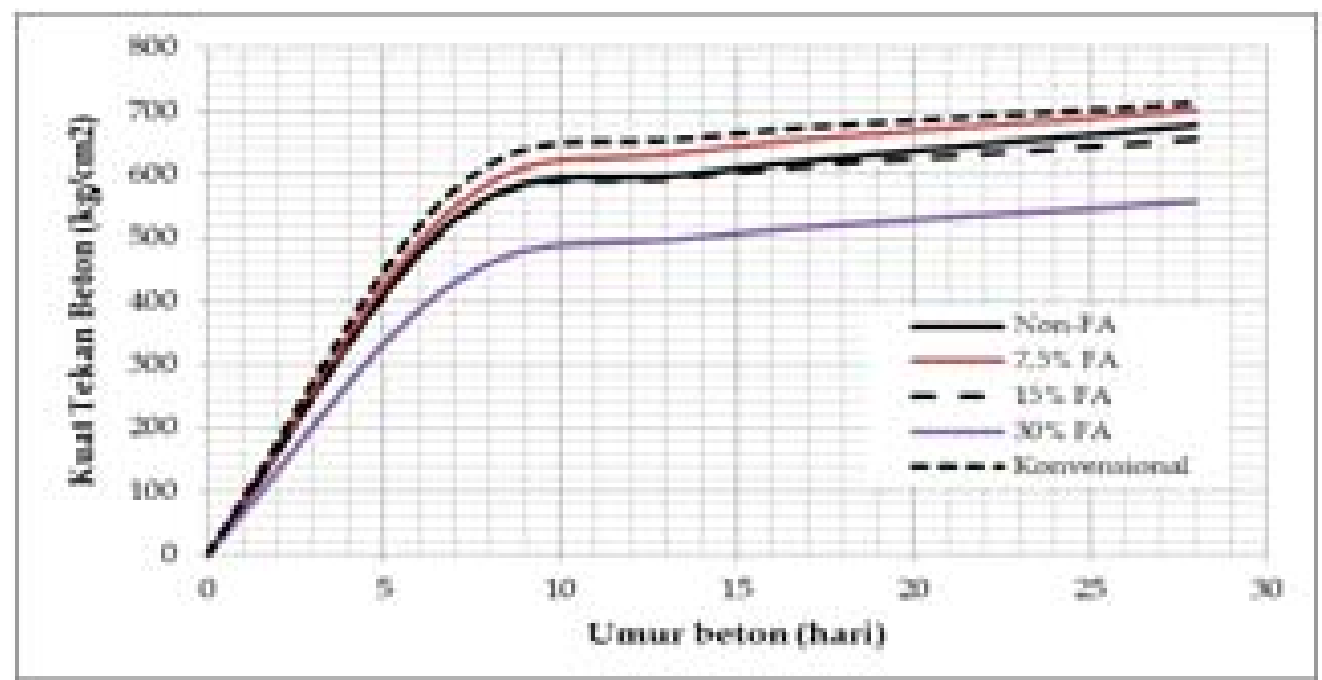

Gambar-4 : Hubungan kuat tekan dan umur beton

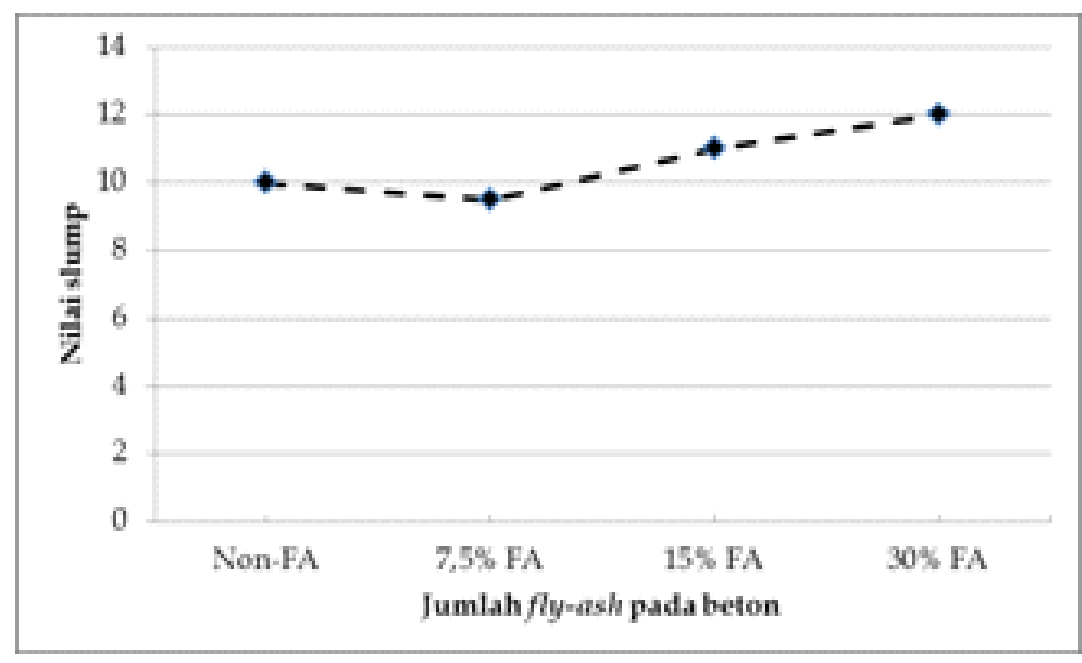

Gambar-5 : Hubungan nilai slump dengan kandungan fly-ash

Pengujian absorbsi beton dilakukan pada saat beton berumur 28 hari, Hasil pengujian absorbsi beton secara lengkap dapat dilihat pada lampiran, dari pengujian absorbsi beton dengan perbedaan variasi penggantian sebagian semen terhadap fly ash dapat dilihat hasilnya pada Tabel-6 
Tabel-6 : Tingkat Penyerapan Beton

\section{Kandungan fly-ash pada campuran beton}

Non FA

$7,5 \%$ FA

$15 \%$ FA

$30 \%$ FA



\section{Gambar-6 : Hubungan tingkat penyerapan dengan kandungan fly-ash}

Gambar-6 menjelaskan bahwa kandungan flyash yang diberikan untuk mengganti sebagian jumlah semen yang digunakan pada campuran beton belum banyak berpengaruh pada tingkat penyerapan beton. Walaupun pada penambahan fly-ash sebanyak 7,5\% memberikan tingkat penyerapan yang paling rendah yakni mencapai $0,21 \%$. Sedangkan pemakaian fly-ash yang berlebih (kandungan fly-ash diatas 7,5\%) justru mengakibatkan tingkat penyerapan beton menjadi bertambah dibandingkan dengan beton tanpa fly-ash. Hal ini sejalan dengan kualitas beton yang juga makin berkurang dengan pemberian fly-ash pada $15 \%$ dan $30 \%$.

\section{UCAPAN TERIMA KASIH}

Peneliti menyampaikan terimakasih yang sebesar-besarnya pada PT WIKA BETON unit Pabrik Beton Pracetak Pasuruan atas kerjasama dan bantuan pemakaian bahan dan laboratorium dalam penelitian ini serta kepada DP2M UMM yang telah bersedia mendanai sebagian dari penelitian ini pada tahun anggran 2011/2012

\section{KESIMPULAN DAN SARAN}

\section{KESIMPULAN}

- Pemakaian fly-ash pada beton sebagai bahan pengganti sebagian semen (cementitious) akan menghasilkan kualitas beton yang kurang baik jika diberikan pada kadar yang relatif banyak (atau lebih dari 7,5\% FA).

Penggunaan perawatan beton dengan metode steam curing hanya akan memberikan percepatan kekuatan awal pada beton dimana pada umur 7 hari dimana kuat tekan beton sudah mencapai 53\% pada beton dengan tanpa fly-ash dan mencapai $47 \%$ pada beton dengan memakai fly-ash sebanyak 7,5\%dari kuat tekan beton umur 28 hari.

Tingkat penyerapan air pada beton belum terlihat signifikan pengaruhnya terhadap pemakaian flyash sebagai cementitious pada beton. Walaupun tingkat penyerapan beton terendah terjadi pada pemakaian fly-ash pada kandungan 7,5\% yakni tingkat penyerapan beton sebesar $0,21 \%$

\section{SARAN}

-- Penggunaan fly-ash terlihat belum memberikan kualitas beton yang signifikan terutama jika dibandingkan dengan beton yang diberi perawatan secara konvensional.

- Material fly-ash perlu dilakukan perbaikan struktur dan komposisi serta karakteristik terlebih dahulu sebelum digunakan sebagai cementitious

\section{DAFTAR PUSTAKA}

ACI Journal, 1965. High Pressure Steam Curing. Journal of The American Concrete Institute.

Alit Karyawan, I Made, 2007, Perbandingan Kuat Tekan dan Permeabilitas Beton yang menggunakan Semen Portland Pozzolan dengan yang menggunakan Semen Portland Tipe-1, Seminar dan Pameran HAKI, Jakarta 
Hidayat,.Hendy, 2008, Pengaruh Metode Perawatan dengan Penguapan (Steam Curing) Terhadap Sifat Mekanik Beton Mutu Tinggi dengan Additif Superplasticiz

Irianti., Laksmi, 2007, Pengaruh Steam Curing terhadap Kekuatan Beton Abu Ketel Mutu Tinggi, Laporan Penelitian

Shan,T.T. 1994. Metode DOE Untuk Perencanaan Rancang Campur Beton Dengan Fly Ash Cement. TA no 573.S, Jurusan Teknik Sipil, Fakultas teknik UK Petra.

Soroushian dan Siavosh Ravanbakhsh, 1999, "High Early Strengh Concrete : Mixture Proportioning with Processed Cellulose Fibres for Durability", ACI Journal vol 96, no 5, Sept-Oct 1999, pp 593-599.

Velosa, AL and MR Veiga,2005, Pozzolanic Materials - Evolution of Mechanical Properties, Int' Building Lime Symposium 2005, Orlando, Florida, USA 